'To William Wordsworth. Composed for the greater part on the same night after the finishing of his recitation of the poem in thirteen books, on the growth of his own mind ' (vide Knight's Life of Wordsworth, ii. p. 184).

thy faithful hopes,

Thy hopes of me, dear friend! by me unfelt!

. Were troublous to me almost as a voice,

Familiar once and more than musical :

As a dear woman's voice to one cast forth,

A wanderer with a worn-out heart forlorn,

'Mid strangers pining with untended wounds.

$O$ friend! too well thou know'st of what sad years

The long suppression had benumbed my soul, That, even as life returns upon the drows'd, The usual joy awoke a throng of pain--

Keen pangs of Love, awakening, as a babe, Turbulent with an outcry in the heart!

And fears self-willed, that shunn'd the eye of hope,

And hope that scarce would know itself from fear ;

Sense of past youth and manhood come in vain,

And genius given and knowledge won in vain;

And all, which I had culled in wood-walks wild,

And all, which patient toil had reared, and all

Commune with TheE had open'd out-but flowers

Strew'd on my corse, and borne upon my bier,

In the same coffin, for the self-same grave.

S. T. Coleridge.

$$
\kappa \in \kappa \alpha \rho \tau \dot{\epsilon} \rho \eta \tau \alpha \iota \quad \tau \dot{\alpha} \mu \alpha \dot{ } .
$$

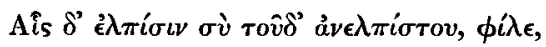

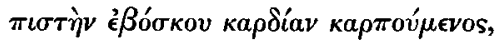

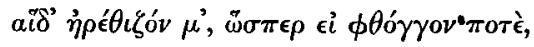

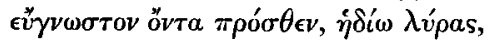

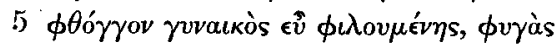

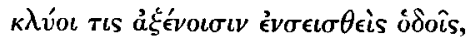

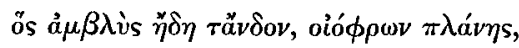

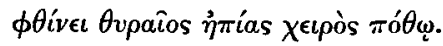

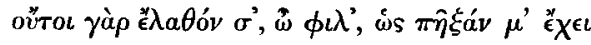

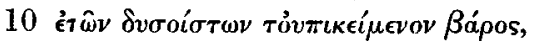

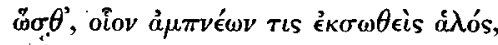

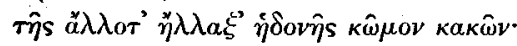

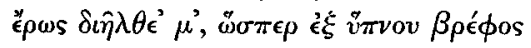

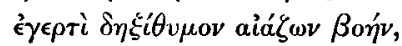

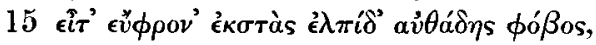

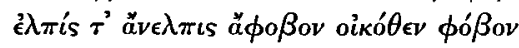

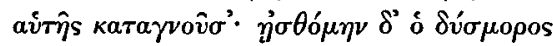

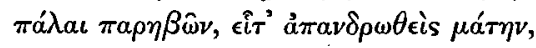

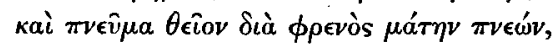

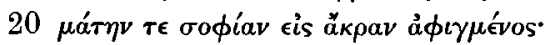

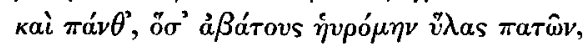

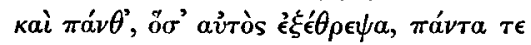

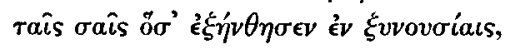
$\phi \epsilon \hat{v}, \lambda v \gamma \rho \grave{a} \kappa \epsilon \hat{\imath} \nu \alpha \nu \hat{v} \nu \mu^{\prime}$ ó $\rho \hat{\omega} \lambda \omega \tau i ́ \sigma \mu \alpha \tau \alpha$

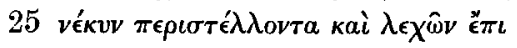

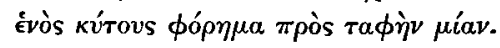

W. T. LENDRUM.

\title{
OBITUARY.
}

\section{HENRY S. FRIEZE, LL.D.}

Professor of the Latin Language and Literature in the University of Michigan,

Died $7 t h$ Dec. 1889.

Is the death of Professor Frieze, not only the University which he served with distinction for more than thirty years, but also the wider circle of classical scholars throughout this country has suffered a great loss.
Hewas born in Boston, Mass., Sept, 15th, 1817. In early youth his family removed to Rhode Island, and he was prepared for college in a private school at Newport. In 1841 he was graduated from Brown University at the head of his class. At once after к 2 
graduation he accepted a tutorship in the University, which position he held for three years, when he became one of the principals of the University Grammar School in Providence. In 1854 he was called to the chair of Latin in the University of Michigan. In connection with Dr. James R. Boise, who was then Professor of Greek, he placed classical studies upon such a broad and sure basis in the young University that, in spite of the Bavavo'a spirit of our day and the strong trend toward scientific studies, the ancient classics have well maintained their position in the college curriculum.

Professor Frieze from the first gave to his teachings what may be called the flavour of a noble realism. As he used to say, he was more desirous that his pupils should be Romans than that they should be Latinists. It was his constant aim to imbue his students with an interest in the old Roman life and literature. Hence from the beginning he accompanied his reading of texts with lectures on Roman history and antiquities. This same spirit became evident in his editorial work. His first edition of the Aeneid, which appeared in 1860, was characterized by fine literary sense, keen insight into the life and thought of the period portrayed by the poet as well as of the Augustan age, and poetic appreciation of the author. It was one of the earliest text-books published in this country to give students the impression that the masterpieces of ancient literature were not written chiefly for the purpose of being the vehicle of grammatical learning; not that Professor Frieze ignored the drier details of linguistic study, but rather that he placed the emphasis upon the literary qualities and the subject-matter of the author in hand.

He had no taste for the pursuit of textual criticism, and was but little interested in the details of purely philological science. But he had rare good judgment and an almost intuitive perception in matters of style and interpretation.

In 1882 he revised his first edition of the Aeneid. The following year he edited the complete works of Vergil, with notes and dictionary, and a separate edition of the Georgics, Bucolics, and the first six books of the Aeneid. The entire work was revised again in 1887 , so as to get the benefit of the most recent studies in Vergil. In 1865 appeared the first edition of the 10 th and 12 th books of Quintilian, based upon the labours of Spalding, Zumpt, and Bonnell. This author had never before been regularly read in an American college, so far as we know, and his value as a field of discipline in literary criticism was first recognized in this country by Prof. Frieze. The edition was greatly improved by a revision made in 1888 , which was the last editorial work of note he accomplished.

By years of study as well as by native endowment, Dr. Frieze was an enthusiastic lover of fine art and became a recognized authority in art criticism. A remarkably fine musician, a devoted student of architecture, sculpture and painting, art studies grew to be in his later years his most absorbing pursuit. For the last ten years he gave courses of lectures on the history of art. Under his fostering care there grew up large collections of casts, photographs, coins and engravings, and in 1886 he put forth a charming biography of Giovanni Dupré together with a translation of two dialogues on art from the Italian of Augusto Conti.

Professor Frieze was twice called to administer the affairs of the University as actingpresident. He was the originator of many of the plans and innovations that have made it a leader in oducational movements. Especially noteworthy are these: the establishing of the organic relation between the University and the High Schools, by which graduates from approved High Schools are admitted into the University without examination; the development of 'the elective system 'and of graduate courses of study; the introduction of the scientific study of music into the regular curriculum.

In his personality Professor Frieze was one of the most delightful of men, ' a pure and beautiful soul' to know whom was a benediction. To the Greek ideal of the $\boldsymbol{o}$ kadòs $\kappa a$ ratós he added the Christian graces of charity and humility.

Michigan University.
M. L. D'OOGE.

\section{ARCH EOLOGY.}

\section{ATHENA PARTHENOS.}

IT would be interesting to know on what principle the Athenians in the early part of the fourth century B.c. employed as a device, representative of the city, at one time the archaic figure of Athena Polias, at another the late type of Athena Parthenos, created 